\title{
Development of Strategic Management Tools and Techniques of Enterprise Competitiveness in the Context of Digitalization
}

\author{
Gunina I.A.* \\ Voronezh State Technical University \\ Voronezh, Russia \\ e-mail:642663@mail.ru \\ Savich Yu.A. \\ Voronezh State Technical University \\ Voronezh, Russia \\ e-mail: vilsavia@mail.ru \\ Kablashova I.V. \\ Voronezh State Technical University \\ Voronezh, Russia \\ e-mail: kablashowa@yandex.ru
}

\author{
Samogorodskaya M.I. \\ Voronezh State Technical University \\ Voronezh, Russia \\ e-mail: Marta17@yandex.ru
}

Voronin S.I.

Voronezh State Technical University

Voronezh, Russia

e-mail: profsiv@mail.ru

Krivyakin K.S.

Voronezh State Technical University

Voronezh, Russia

e-mail: brad@bk.ru

\begin{abstract}
The effective strategic management of the competitiveness of domestic enterprises directly depends on the understanding of the development prospects, mission, and vision of the company's future by top management and employees. Due to the modern conditions of a rapidly changing business environment, we have to find new ways of competitive advantage management and new strategies to be successful. The development of modern economic science is focused on the creation of universal methods and management tools and techniques that could ensure the competitive development of enterprises. However, the rapidly changing business environment is the reason for the occurrence of barriers, such as the absence of a clearly defined strategy, misunderstanding of tools and methodologies, inability to foresee prospects for developing, inertia caused by excessive bureaucratization of the management system.
\end{abstract}

Keywords - competitiveness, management, strategy, management tools, mission, competitive advantage, strategic management tools, digitalization.

\section{INTRODUCTION}

Goals, choice, resources, and efficiency are the fundamentals of enterprise competitiveness management. It is necessary to analyze and evaluate each of these aspects to build strategic targets and plans. Additional risks for the implementation of enterprise targets are developing due to dynamically changing business environmental conditions. A high degree of uncertainty must be taken into account to determine goals and targets when formatting a competitiveness management system. It happens because of the lack of access to all available information.

The competitiveness of the organization is determined by the potential of the enterprise, aimed at the formation of competitive advantages used to achieve results in relevant market conditions. Elements of enterprise competitiveness are product competitiveness, production competitiveness, personnel, innovative potential of the enterprise and the totality of resources inherent to the enterprise aimed at achieving the strategic goals of the enterprise.

It is necessary to consider the concept and composition of tools that will allow the company to effectively develop strategic competitiveness, before moving on to research the structural and logical development of strategic management tools and techniques.

There is no clear definition and structural justification for the concept of the instrument because it is often found among the definitions of the humanities and economics. The objective of this study is to formulate a scientific and structurally logical justification of the terms "Instrument" and "Tool".

\section{METHODOLOGY AND ANALYSIS}

If we consider the definition outside a specific scientific field, the "instrument" is a mechanism, machine tool or algorithm designed to perform certain tasks, as well as to measure various indicators [1]. In the economic dictionary, the term instrument is explained as a means of regulation, management of various economic phenomena and processes [2].

The authors considered the existing criteria that allow defining the instrument as an independent scientific concept to substantiate the application of the proposed terminology. Scientifically, the instrument of scientific knowledge is a method that allows you to make management activities the most efficient and appropriate. The order of application of the methods is determined by the methodology [3]. 
Researcher of economic philosophy D. Houseman believes that economic science should include a full range of mathematical and analytical instruments that allow you to achieve maximum results [4].

Following the philosophy study, the instrument is part of the instrumental theory, which assumes that all processes of the social world, theories, and concepts in which control can be implemented. The instrumentalists assumed that ideas, theories are means that introduce certainty and order into reality. F. Taylor was a proponent of instrumentalism in management. $\mathrm{He}$ considered management through a mechanistic approach [5]. Thus, we can conclude that any economic theory can be used as a scientific instrument for changing paradigms and concepts According to I. Ansoff, it is possible to consider the strategic management paradigm as an enterprise's competitiveness. This is the procedure for implementing managerial impact on the target indicators of the enterprise in the turbulent business environment and analytical instruments that allow achieving strategic success [6].

Following the study, the authors concluded that the instrument is an integral part of management that has an impact on the processes and measures the effect. The importance of the topic under study is related to the fact that the complexity of management processes is gradually increasing, which may negatively affect the expected results [11].

The key to the competitiveness of the enterprise is the proper use of strategic management instruments, which should provide flexible and adaptive support for the development of the enterprise and the phased implementation of strategic plans, ensuring sustainable development of the enterprise and its competitive advantages. Figure 1 shows the relationship between competitiveness and enterprise strategy.

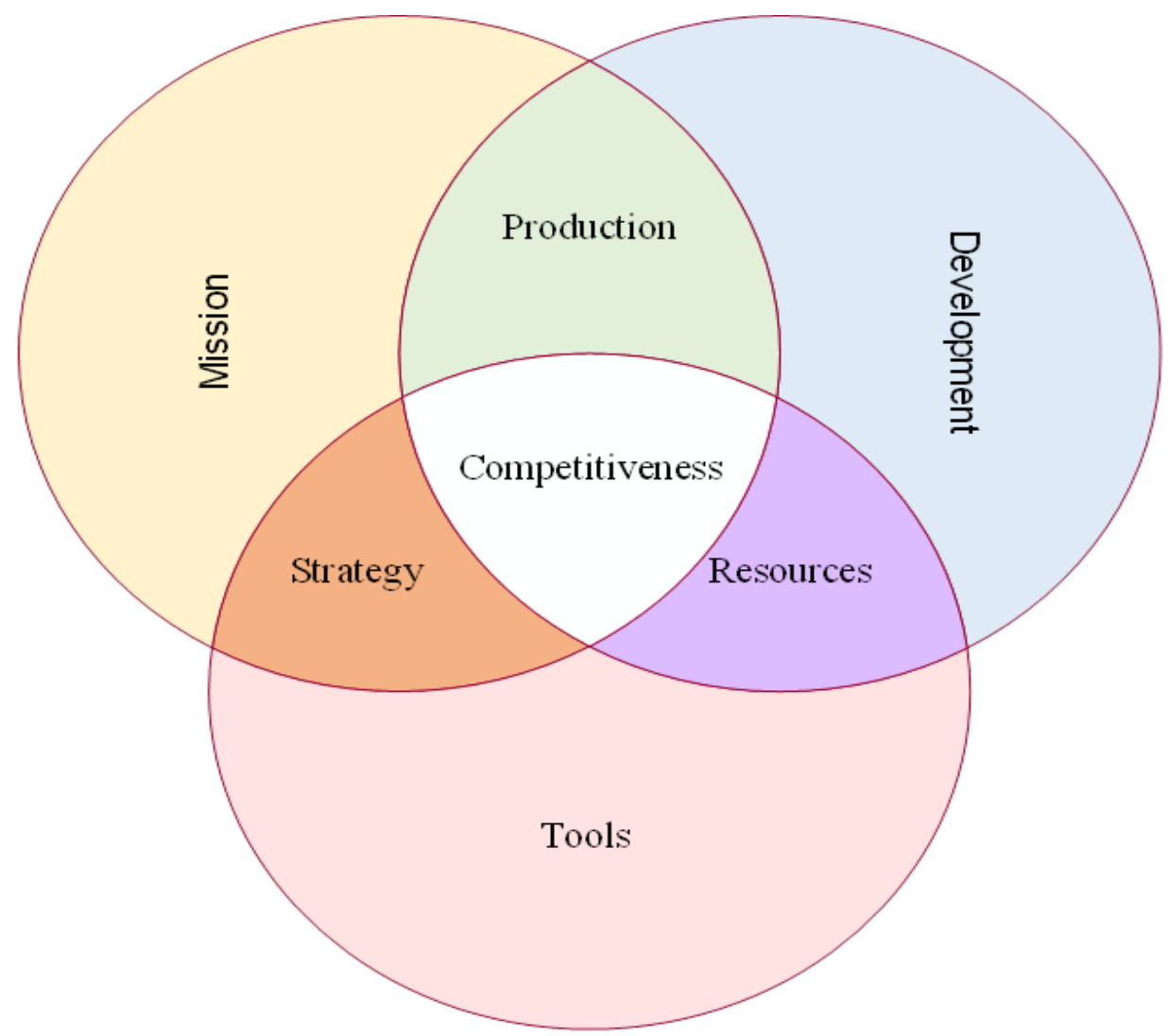

Fig. 1. Competitiveness in Euler and Venn diagram

Figure 2 shows the classification scheme of strategic management instruments proposed by the authors.

The compliance of the proposed instrument with the targets of strategic management of enterprise competitiveness can be assessed through management functions. Functional instruments will be graded on organizational, planning, motivational, control and analytical.

According to the timing of the implementation of strategic management tasks, instruments can be differentiated as operational, tactical and long-term. 


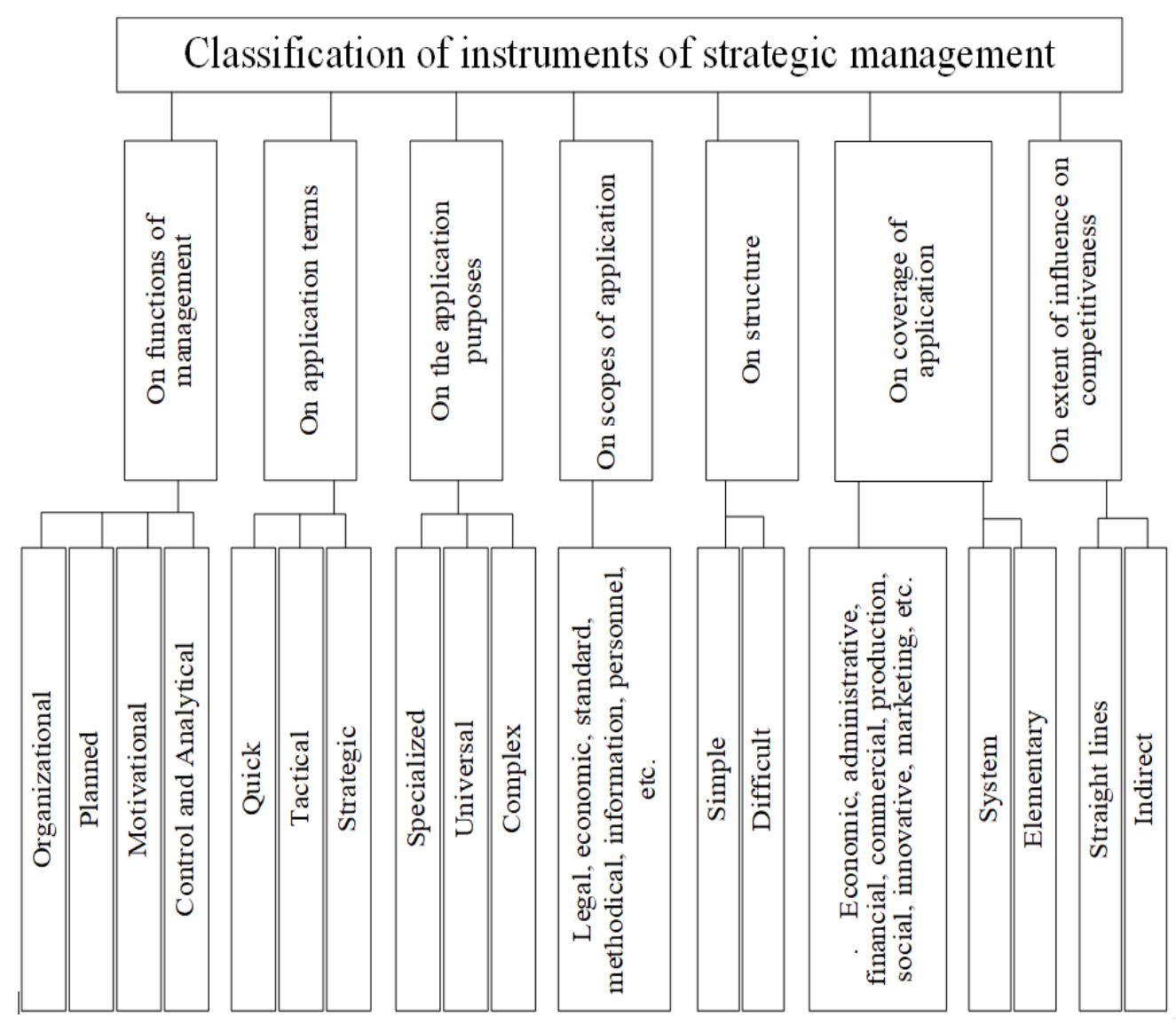

Fig. 2. Classification of instruments for the strategic management of enterprise competitiveness

Instruments can be graded depending on its ability to meet the challenges of competitiveness management:

- specialized, intended for specific tasks of enterprise competitiveness management;

- universal, suitable for solving most strategic management tasks

- complex, aimed at solving several management tasks at once to achieve the goals of strategic management of enterprise competitiveness.

According to the purpose of the application, the instruments can be graded as legal, economic, regulatory, methodological, informational, personnel, etc.

The composition of the instruments can be differentiated as simple, represented by single simple algorithms and methods, and complex, including complete methods and mechanisms.

The application of instruments is aimed at the implementation of certain tasks depending on the scope of the enterprise, such as economic, managerial, financial, commercial, industrial, social, innovative, and marketing.

According to the purpose of the application, the instruments are divided according to the priorities of achieving global, core. The author believes that the target instruments should be defined as a separate group since in this case, it will reflect the compliance of the achieved indicators with the goals of competitiveness management. into:

By scope of application, the instruments can be divided

- system instruments, covering most elements of the enterprise competitiveness management system;

- elementary, intended to solve highly specialized tasks.

The last paragraph describes the strategic instrument as having a direct and indirect effect on the competitiveness of the enterprise, as well as the strength of the effect.

In foreign practice, much attention is paid to the study of strategic management instruments. Annually, the most popular tools, trends and directions of development of managerial tools are defined in "management tools and trends" collection [5].

In 1993, an analysis of the popularity of strategic instruments had been initiated. This analysis has caused several changes. However, the methods of using instruments demonstrate a certain stability, which proves its efficiency and relevance.

In combination, management instruments can cover the full range of business cycles, regardless of industry or size. 
Business cycles and changing management theories influence the popularity of individual instruments and trends (table 1Based on the study, you can see how the top ten most popular strategic management tools have changed. Often, the popular instrument disappears from the list, but an improved version of the instrument can later be used.

TABLE I. DEVELOPMENT OF MANAGEMENT INSTRUMENTS.

\begin{tabular}{|c|c|c|c|c|}
\hline № & 1993 & 2000 & 2014 & 2017 \\
\hline 1 & $\begin{array}{l}\text { Mission and } \\
\text { Vision of Business } \\
(\mathbf{8 8 \%})\end{array}$ & $\begin{array}{l}\text { Strategy } \\
\text { planning }(76 \%)\end{array}$ & $\begin{array}{l}\text { Customer } \\
\text { relationship } \\
\text { management } \\
(46 \%)\end{array}$ & $\begin{array}{l}\text { Strategy planning } \\
(48 \%)\end{array}$ \\
\hline 2 & $\begin{array}{l}\text { Customer } \\
\text { satisfaction }(86 \%)\end{array}$ & $\begin{array}{l}\text { Mission and } \\
\text { Vision of } \\
\text { Business }(\mathbf{7 0 \%})\end{array}$ & $\begin{array}{l}\text { Benchmarking } \\
(44 \%)\end{array}$ & $\begin{array}{l}\text { Customer } \\
\text { relationship } \\
\text { management } \\
(48 \%)\end{array}$ \\
\hline 3 & $\begin{array}{l}\text { Total Quality } \\
\text { Management } \\
(72 \%)\end{array}$ & $\begin{array}{l}\text { Benchmarking } \\
(69 \%)\end{array}$ & $\begin{array}{l}\text { Staff involvement } \\
(44 \%)\end{array}$ & $\begin{array}{l}\text { Benchmarking } \\
(46 \%)\end{array}$ \\
\hline 4 & $\begin{array}{l}\text { Development of } \\
\text { competitive } \\
\text { advantages }(71 \%)\end{array}$ & $\begin{array}{l}\text { Outsourcing } \\
(63 \%)\end{array}$ & $\begin{array}{l}\text { Strategy planning } \\
(44 \%)\end{array}$ & $\begin{array}{l}\text { Advanced and } \\
\text { Big Data } \\
\text { Analytics }(42 \%)\end{array}$ \\
\hline 5 & $\begin{array}{l}\text { Benchmarking } \\
(70 \%)\end{array}$ & $\begin{array}{l}\text { Customer } \\
\text { satisfaction } \\
(60 \%)\end{array}$ & $\begin{array}{l}\text { Outsourcing } \\
(41 \%)\end{array}$ & $\begin{array}{l}\text { Supply of Chain } \\
\text { Management } \\
(40 \%)\end{array}$ \\
\hline 6 & $\begin{array}{l}\text { Productivity fee } \\
(70 \%)\end{array}$ & $\begin{array}{l}\text { Growth strategy } \\
(55 \%)\end{array}$ & \begin{tabular}{|l} 
Balanced \\
Scorecard $(38 \%)$
\end{tabular} & $\begin{array}{l}\text { Customer } \\
\text { satisfaction } \\
(38 \%)\end{array}$ \\
\hline 7 & $\begin{array}{l}\text { Reengineering } \\
(67 \%)\end{array}$ & $\begin{array}{l}\text { Strategic alliance } \\
(53 \%)\end{array}$ & $\begin{array}{l}\text { Mission and } \\
\text { Vision of } \\
\text { Business }(38 \%) \\
\end{array}$ & $\begin{array}{l}\text { Supply Chain } \\
\text { Management } \\
(34 \%)\end{array}$ \\
\hline 8 & $\begin{array}{l}\text { Strategic alliance } \\
(62 \%)\end{array}$ & $\begin{array}{l}\text { Productivity fee } \\
(52 \%)\end{array}$ & $\begin{array}{l}\text { Supply Chain } \\
\text { Management } \\
(36 \%)\end{array}$ & $\begin{array}{l}\text { Total Quality } \\
\text { Management } \\
(\mathbf{3 4 \%}) \\
\end{array}$ \\
\hline 9 & $\begin{array}{l}\text { Cycle Reduction } \\
(55 \%)\end{array}$ & $\begin{array}{l}\text { Customer } \\
\text { segmentation } \\
(51 \%) \\
\end{array}$ & $\begin{array}{l}\text { Management of } \\
\text { Change }(34 \%)\end{array}$ & \begin{tabular}{|l} 
Digital \\
transformation \\
$(32 \%)$ \\
\end{tabular} \\
\hline 10 & $\begin{array}{l}\text { Self-managing } \\
\text { group }(55 \%)\end{array}$ & $\begin{array}{l}\text { Core competency } \\
\text { development } \\
(48 \%)\end{array}$ & $\begin{array}{l}\text { Customer } \\
\text { segmentation } 30\end{array}$ & $\begin{array}{l}\text { Mission and } \\
\text { Vision of } \\
\text { Business }(32 \%)\end{array}$ \\
\hline
\end{tabular}

The research results in table 1 show that the development of information technology and the digitalization of the economy are gradually changing the existing arrangement. This has an impact on the development of macro-, micro- and mesoeconomics at the global level [8].

The intended to break down established management paradigms and organizational concepts have the effect of modifying the perception of competition and competitive advantages. The management structure is changing, management principles come first, companies are abandoning its usual hierarchies, Agile Management instruments are spreading more and more, all this accelerates the innovation process and changes the strategic direction of enterprise development. It leads to the fact that enterprise management is gradually changing its attitude to management methods and begins to seek new ways of strategic development to consolidate its competitive positions.

The expert agency Bain \& Company surveyed the leaders of the largest enterprises around the world about the goals and targets that modern economy and technology development challenge them, which areas, development trends, and strategic instruments [7].
Below, we consider the main instruments, the importance of which was rated by top management. In total, 25 instruments were allocated, but not all instruments are suitable for strategic management.

Changes in economic structures affect the priorities of the enterprise, as well as factors of the external and internal business environment [8].

On the one hand, in connection with the transition to a new economic structure, enterprises receive previously inaccessible advantages, which, as it seemed, should help to increase the level of competitiveness. All this is associated with a reduction in communication costs - the Internet, the unification of communication methods, by the aid of the development of computer technology and the transmission of information in digital form [10]. On the other hand, the complexity of management and bureaucratization of processes is increasing; this contradicts the development of the enterprise and the introduction of a digital economy.

\section{DISCUSSION AND RESULTS}

Agile is a flexible instrument that is the dominant factor in all industrial sectors. This instrument is based on increasing the value of innovation. Agile, the flexible instrument, was borrowed from software developers. Japanese enterprises are leaders for the application of this instrument. Managers need to adapt the company to IT capabilities and business needs in the coming years. Only the leaders of the digital economy can guarantee themselves competitive advantages.

The mission of the enterprise is the important strategic management instrument for competitiveness. This instrument resonates with the corporate culture because the mission is not only the consumers' view of the company but also how the company is perceived by the employees, the existence of the enterprise depends on the employees. In this case, the mission is aimed at strengthening the corporate culture. Creating an effective corporate culture is the key to a long-term business success strategy.

Industrial enterprises also need to consider the importance of the consumer factor. The use of the instrument should be aimed at maintaining the attractiveness of its products, ensuring stable performance and product quality. It will help achieve the expected strategic results.

The versatility of management instruments and its structural components should be taken into consideration at all stages of the formation of a competitiveness management strategy. The specialist must understand that you cannot use only one instrument or a set of instruments without taking into consideration those tasks that must be solved to achieve strategic goals. The continuity and interconnection of used instruments should be taken into consideration in the competitiveness management system.

Instruments should be used comprehensively, based on an understanding of the advantages, disadvantages, features and limitations of each instrument. The correct use of instruments will allow a qualitative impact on the competitiveness of the enterprise. Also, enterprises need to combine the instruments of managing, analytical and controlling influence. 
The process of strategic management of competitive advantages in the context of digital transformation is associated with the use of digital technologies. The integration of strategic management instruments, digital technologies, big date, agile allows for the effective implementation of management goals. However, many enterprises do not consider the factor of digital transformation and digitalization in their strategy. It happens because enterprises combined into collaboration are distinguished by a complex bureaucratic structure. This approach makes it difficult to quickly adapt to constantly changing conditions. $[9,10]$.

The tools and techniques of strategic competitiveness management include a specific set of instruments. The effectiveness of the tools and techniques of strategic competitiveness management consists of the sound management of the enterprise based on the choice of strategic decisions. Such solutions make it possible to achieve an optimal balance between production potential, successful financial activities, competitiveness, and quality of products.

Justification of tools and techniques for the strategic management of enterprise competitiveness must be carried out, based on the theory of the use of instruments to maximize the use of enterprise resources. Efficiency is the cornerstone of competitiveness, which entails the mobilization of the resources available to the enterprise.

The application of any instrument for the implementation of strategic competitiveness management tasks is associated with an understanding of the structure, which is characteristic of all instruments and can be defined as a combination of theoretical and methodological knowledge of the impact algorithm and the practice of its implementation in certain conditions.

Enterprises need to be guided by world practice, as well as a change in the economic structure that is happening at present. At the moment, there is a certain effect on the prospects for prosperity and enterprises need to develop own instruments and methods for their integrated use.

\section{CONCLUSION}

Goals and targets of the tools and techniques of strategic management of enterprise competitiveness.

1. The use of tools and techniques for the strategic management of the enterprise's competitiveness is aimed at implementing the global and strategic goals of the enterprise and it is also its life support system.

2. Tools and techniques of strategic management should include methods and models that allow for the appearance of negative factors, as well as prevent or reduce their impact on the enterprise ecosystem.

3. Tools and techniques of the strategic competitiveness management of the enterprise affects various management components and its functions: organizational, economic, social, financial, production, information, technological, psychological, combined in one management mechanism aimed at fulfilling the needs of society, increasing their complementarity and reducing conflicts in the ecosystem enterprises [6].

4. Tools and techniques of the strategic management of enterprise competitiveness with varying strength have an impact on the relationship between the subsystems at each stage of production activity.

5. The use of tools and techniques for the strategic management of enterprise competitiveness performs the functions of regulation and updating by field of activity.

6. The use of tools and techniques for the strategic management of enterprise competitiveness is aimed at the timely identification of competitive advantages and analysis of the enterprise's competitive business environment.

7. The integration of management instruments and digital technologies in all aspects of the enterprise is not so much a competitive advantage as a vital necessity, a mandatory requirement for a competitor.

8. Tools and techniques of the strategic competitiveness management of the enterprise include human resources management tools as the company's main strategic potential.

\section{References}

[1] D.N. Ushakov, Explanatory Dictionary of the Russian Language. Moscow: State Inst. of "Soviet encyclopedia"; Associat. of State Book and Magazine Publ.; State Publ. House of Foreign and national words, pp. 1935-1940.

[2] P.A. Koshel, Reference Dictionary: Economics, Foreign Trade, Exhibitions. Moscow: Publ. House of the Preservat. of Literary Heritage, 2012, 344 p.

[3] V.A. Kanke, Philosophy of Economics: A Study Guide. Moscow: INFRA-M, 2009, p. 384

[4] D. Hauschan, Philosophy of Economics. Anthology. Moscow: Publ House of the Instit. Gaidar, 2012, 520 p.

[5] F. Taylor, Principles of Scientific Management. Moscow: Controlling, $1991,104 \mathrm{p}$.

[6] I. Ansoff, Strategic management. Moscow: Economics, 1989, 519 p.

[7] Management Tools \& Trends, Retrieved from https://www.bain.com/contentassets/caa40128a49c4f34800a76eae15828 e3/bain_brief-management_tools_and_trends.pdf)

[8] O. Kolomytseva, E. Kolesnikova, I. Gunina, V. Agafonova, "Management of the innovative ecosystem development environment", E3S, p. 08067, 2019.

[9] "Industry 4.0": creation of a digital enterprise. Worldwide Implementation Overview "Industry 4.0" for 2016, Retrieved from: http: Ilwww.pwc.com/industry40 (date of the application: 25.10.2018)

[10] U.A. Savich, "Digital transformation and its impact on the competitiveness of industrial enterprises", Econominfo, vol. 15, no. 4, pp. 44-48, 2018.

[11] G. Zenina, I. Gunina, T. Narolina, Y. Pahomova, O. Dudareva, "Development of human capital in the context of digital transformation", Sustainable Economic development, Innovation Management, and Global Growth, pp. 4297-4303, 2017 [Proc. of the 30th Int. Busin. Inform. Manage. Associat. Confe., IBIMA 2017 - Vision 2020]. 